\title{
Experimental infections of rabbits and guineapigs with Trichostrongylus axei (Cobbold, 1879) Railliet and Henry, 1909.
}

\author{
by V.S. PANDEY \\ Prince Leopold Institute of Tropical Medicine, Antwerp, Belgium. \\ and Faculty of Veterinary Medicine, Rue des Vétérinaires 45, 1070 Brussels, Belgium.
}

\section{Summary}

Rabbits and guineapigs were inoculated with different doses of infective larvae of Trichostrongylus axei per os and autopsied on 7th, 14th and 28th days after infection. The total number of worms recovered increased with the dose of the larvae administered but the percentage establishment of the worms decreased with increase in dose of the infective larvae. The worms were localised in stomach and small intestine; the majority being recovered from the stomach. The infected rabbits and guineapigs either lost weight or gained less weight than those of non-infected animals. The worms recovered on 7 th and 14th days were immature while those on 28th day were adult. The size of the worms was smaller than those from the normal hosts.

Rabbit was found to be a suitable host for experimental studies on Trichostrongylus axei. Guineapig was considered to be a relatively less receptive host for this parasite.

\section{Résumé}

Infections expérimentales de lapins et de cobayes par Trichostrongylus axei (Cobbold, 1879), Railliet et Henry, 1909.

Les différentes doses de larves infestantes de Trichostrongylus axei ont été administrées per os aux lapins et aux cobayes. Les animaux étaient autopsiés les $7^{\mathrm{e}}$, $14^{\mathrm{e}}$ et $28^{\mathrm{e}}$ jours après l'infection. Le nombre total de vers retrouvés augmentait avec la dose des larves administrées mais le pourcentage des vers établis diminuait avec l'augmentation de la dose

Present address: Faculté de Médecine vétérinaire, Université nationale du Zaïre, Campus de Lubumbashi, B.P. 1825, Lubumbashi, République du Zaïre. 
des larves. Les vers étaient localisés dans l'estomac et dans l'intestin grêle, la majorité de ceux-ci a été retrouvée dans l'estomac. Les lapins et les cobayes infectés ont perdu ou ont gagné un poids inférieur à celui des animaux non-infestés. Les vers recueillis les $7^{\mathrm{e}}$ et $14^{\mathrm{e}}$ jours étaient immatures tandis que ceux du $28^{\mathrm{e}}$ jour étaient adultes. La taille des vers était plus petite que celle des vers de l'hôte normal.

On a constaté que le lapin est un hôte convenable pour l'étude expérimentale de Trichostrongylus axei. Le cobaye est considéré comme un hôte relativement peu réceptif à ce parasite.

Trichostrongylus axei is recognised as an important pathogen of ruminants and horses in many parts of the world. Its natural infection in a wild rabbit in New Zealand was reported by Bull (1953). Drudge et al. (1955) for the first time successfully infected rabbits with equine, bovine and ovine strains and guineapigs with the equine and bovine strains of $T$. axei. Leland and Drudge (1957) made studies on quantitative aspects of experimental infections in rabbits. Thereafter the rabbits have been used in some more studies (Rohrbacher, 1960 ; Ciordia et al., 1966; Sinha, 1967). Cauthen (1958) reported that rabbits are not satisfactory animals for tests of anthelmintics to be used against $T$. axei in ruminants.

High costs of domestic animals is a limiting factor in their use for experimental purposes in the study of nematodes like $T$. axei. Technically and economically it is more easier and advantageous to maintain and study a pathogen of large domestic animals in small laboratory animals. This prompted us to take up this study. The value of guineapigs as laboratory host of this parasite was tested in detail. At the same time some experiments on rabbits were also made to verify the previous reports.

\section{Materials and methods}

Young rabbits and guineapigs bred and reared in the laboratory were used. They were kept either individually or in groups in wire mesh cages. Commercial pelleted food and water was supplied daily ad. lib. Both male and female animals were used.

$T$. axei was maintained as a pure infection by administering infective larvae to a worm free calf. This calf served as the source of infective larvae. The faeces obtained from the rectum were cultured at $25^{\circ} \mathrm{C}$ for 2 weeks and the infective larvae recovered by baermannization. All the animals were dosed with the larvae from the same suspension. Only freshly harvested larvae were used.

The required number of infective larvae suspended in water were administered per os, using a syringe fitted with a $8 \mathrm{~cm}$. length of plastic tubing for guineapigs and a more longer tube for rabbits. After administration of the larval dose the syringe and tubing were washed with $0.5 \mathrm{ml}$. of water and this 'wash' was also administered. The whole larval dose was concentrated in not more than $2 \mathrm{ml}$. of water for guineapigs and $5 \mathrm{ml}$. for rabbits.

The animals were killed by ether or chloroform vapour. Immediately afterwards, stomach and small intestine were seperated. The stomach was opened, its contents 
removed and then placed in pepsin-hydrochloric acid digestion fluid (Herlich, 1956). The intestine was cut into small pieces and placed in another container filled with the same digestion fluid. Digestion was allowed to proceed over night at $37^{\circ} \mathrm{C}$. The stomach contents and digests of stomach and intestine were poured onto a 100 and then onto a 200 mesh sieve to allow small particles and fluid to pass through. The material retained on the sieve was washed off carefully by a jet of water. The search was made with the aid of a dissecting microscope for the recovery of the worms. If immediate counting was not possible, whole material was preserved in $10 \%$ formaline.

Sixteen rabbits were used in the experiments. Two larval doses were utilised : 4,000 and 8,000. For 4,000 larval dose level, 1 animal was autopsied on day 7, 2 animals were autopsied on day 7,2 on day 14 and 3 on day 28 post infection. Three animals were autopsied on day 7.2 on day 14 and 3 on day 28 post infection. Three rabbits were kept as controls. All the rabbits were weighed at the beginning of the experiments. Those distined to be sacrificed on day 28 post infection and control group were weighed weekly to follow the live body weight changes.

Seventy guineapigs, divided into 10 equal groups, were used. Each group had animals of both sexes. Three levels of larval doses were utilised : 1,000, 4,000 and 8,000 . Three groups of animals were infected with each dose level. Thus there were 9 experimental and 1 control group. One group from each dose level was autopsied on days 7, 14 and 28 days post infection. To follow the changes in the body weight, the guineapigs destined to be autopsied on 28th day and control group were weighed weekly. All other animals were weighed only at the beginning of the experiment.

\section{Results}

\section{Rabbits.}

Data pertaining to sex, initial body weight, larval doses, days of autopsy and the worms recorvered on post mortem are presented in table I.

Number of worms increased with the dose of the larvae. But the percentage establishment did not increase even when the larval dose was doubled. Analysis of variance showed that there was no significant difference between the percentage worm recoveries from rabbits of different groups. Although many of the females harboured lesser number of worms than the males, the individual differences were so high that it may be assumed that there were no real differences between the susceptibility of male and female rabbits.

The worms were distributed in stomach as well as in the small intestine. Although in some rabbits a significantly good number of worms were found in the small intestine the majority of them were located in the stomach.

The mean body weight gains of different groups of rabbits are presented in fig. 1. Animals in all groups put weight. Statistical analysis showed that a trend was 
Table I. - Recovery of Trichostrongylus axei from rabbits.

\begin{tabular}{|c|c|c|c|c|c|c|c|c|}
\hline \multirow{2}{*}{$\begin{array}{c}\text { Rabbit } \\
\mathbf{N}^{\circ}\end{array}$} & \multirow{2}{*}{ Sex } & \multirow{2}{*}{$\begin{array}{l}\text { Weight } \\
\text { (gm) }\end{array}$} & \multirow{2}{*}{$\begin{array}{l}\text { Dose of } \\
\text { larvae }\end{array}$} & \multirow{2}{*}{$\begin{array}{l}\text { Days } \\
\text { from } \\
\text { infection } \\
\text { to } \\
\text { autopsy }\end{array}$} & \multicolumn{3}{|c|}{ Worms recovered } & \multirow{2}{*}{$\begin{array}{c}\text { Percent } \\
\text { of larvae } \\
\text { adminis- } \\
\text { tered }\end{array}$} \\
\hline & & & & & Stomach & $\begin{array}{c}\text { Small } \\
\text { intestine }\end{array}$ & Total & \\
\hline 1 & $\mathrm{~F}$ & 1750 & 4.000 & 7 & 890 & 120 & 1010 & 25,3 \\
\hline 2 & M & 2580 & 4.000 & 14 & 700 & 200 & 900 & 22,5 \\
\hline 3 & M & 1305 & 4.000 & 14 & 480 & 150 & 630 & 15,8 \\
\hline 4 & $\mathbf{M}$ & 2400 & 4.000 & 28 & 1050 & 150 & 1200 & 30,0 \\
\hline 5 & $\mathrm{~F}$ & 1420 & 4.000 & 28 & 890 & 50 & 940 & 23,5 \\
\hline 6 & $\mathbf{M}$ & 1800 & 4.000 & 28 & 1000 & 45 & 1045 & 26,1 \\
\hline 7 & $\mathrm{~F}$ & 1420 & 8.000 & 7 & 1800 & 200 & 2000 & 25,0 \\
\hline 8 & M & 1440 & 8.000 & 7 & 1550 & 250 & 1800 & 22,5 \\
\hline 9 & $\mathrm{~F}$ & 1765 & 8.000 & 14 & 1100 & 500 & 1600 & 20,0 \\
\hline 10 & M & 1910 & 8.000 & 14 & 1500 & 200 & 1700 & 21,3 \\
\hline 11 & $\mathrm{~F}$ & 1820 & 8.000 & 28 & 1080 & 325 & 1405 & 17,6 \\
\hline 12 & $\mathbf{M}$ & 2055 & 8.000 & 28 & 1300 & 785 & 2085 & 26,1 \\
\hline 13 & $\mathrm{~F}$ & 1755 & 8.000 & 28 & 990 & 310 & 1300 & 16,3 \\
\hline
\end{tabular}

$\mathrm{M}=$ Male.

$\mathrm{F}=$ Female.

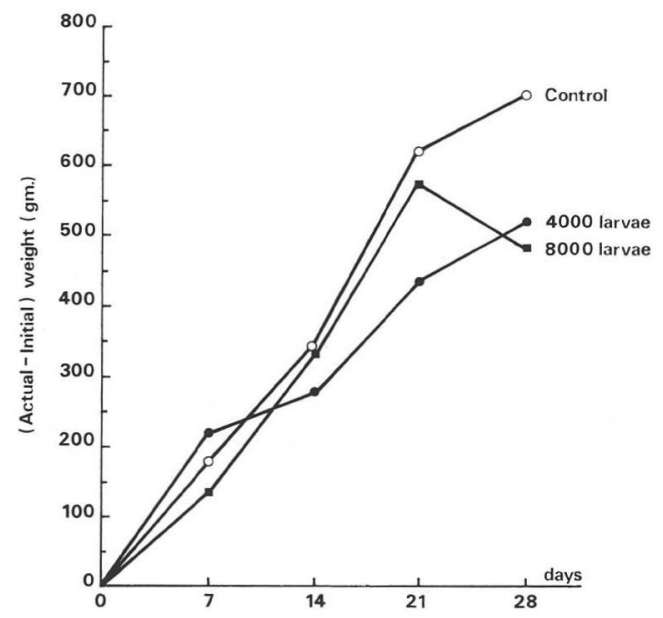

observed in the weight gain of animals according to the dose of the larvae. The increase in weight was continuous in control group and in the group of 4,000 larval dose, whereas in the group of the 8,000 larval dose there was a drop in weight gain in the 4th week. This corresponds with the time when the worms become mature. It seems, therefore, that a minimum of 8,000 larvae are necessory to have an appreciable effect on the body weight gain of rabbits.

FIG. 1. - Mean body weight changes of 3 groupes of rabbits 


\section{Guineapigs.}

Data pertaining to sex, body weight, larval dose, days of autopsy and worm recoveries on post mortem examination are given in tables II, III, IV.

Table II. - Recovery of Trichostrongylus axei from guineapigs infected with 1000 larvae.

\begin{tabular}{|c|c|c|c|c|c|c|c|}
\hline \multirow{2}{*}{$\begin{array}{c}\text { Guineapig } \\
\text { No. }\end{array}$} & \multirow{2}{*}{ Sex } & \multirow{2}{*}{$\begin{array}{c}\text { Weight } \\
\text { (gm) }\end{array}$} & \multirow{2}{*}{$\begin{array}{c}\text { Days } \\
\text { from } \\
\text { infection } \\
\text { to } \\
\text { autopsy }\end{array}$} & \multicolumn{3}{|c|}{ Worms recovered } & \multirow{2}{*}{$\begin{array}{c}\text { Percent } \\
\text { of larvae } \\
\text { adminis- } \\
\text { tered }\end{array}$} \\
\hline & & & & Stomach & $\begin{array}{c}\text { Small } \\
\text { intestine }\end{array}$ & Total & \\
\hline 1 & M & 545 & Died & - & - & - & - \\
\hline 2 & M & 700 & 7 & 140 & 10 & 150 & 15.0 \\
\hline 3 & M & 300 & 7 & 90 & 0 & 90 & 9.0 \\
\hline 4 & $\mathrm{~F}$ & 450 & 7 & 130 & 15 & 145 & 14.5 \\
\hline 5 & $\mathrm{~F}$ & 440 & 7 & 45 & 0 & 45 & 4.5 \\
\hline 6 & $\mathrm{~F}$ & 400 & 7 & 0 & 0 & 0 & 0.0 \\
\hline 7 & $\mathrm{~F}$ & 325 & 7 & 10 & 0 & 10 & 1.0 \\
\hline \multicolumn{2}{|c|}{ Average } & 451 & & 69 & 4 & 73 & 7.3 \\
\hline 8 & $\mathrm{~F}$ & 355 & Died & - & - & - & - \\
\hline 9 & F & 365 & 14 & 45 & 25 & 70 & 7.0 \\
\hline 10 & $\mathrm{~F}$ & 365 & 14 & 100 & 10 & 110 & 11.0 \\
\hline 11 & $\mathrm{~F}$ & 360 & Died & - & - & - & - \\
\hline 12 & M & 220 & 14 & 90 & 40 & 130 & 13.0 \\
\hline 13 & M & 260 & 14 & 15 & 0 & 15 & 1.5 \\
\hline 14 & M & 305 & 14 & 0 & 0 & 0 & 0.0 \\
\hline \multicolumn{2}{|c|}{ Average } & 319 & & 50 & 15 & 65 & 6.5 \\
\hline 15 & $\mathrm{~F}$ & 555 & 28 & 0 & 0 & 0 & 0.0 \\
\hline 16 & $\mathrm{~F}$ & 385 & 28 & 40 & 50 & 90 & 9.0 \\
\hline 17 & M & 260 & 28 & 45 & 35 & 80 & 8.0 \\
\hline 18 & M & 340 & 28 & 100 & 25 & 125 & 12.5 \\
\hline 19 & M & 405 & 28 & 15 & 5 & 20 & 2.5 \\
\hline 20 & M & 320 & 28 & 35 & 15 & 50 & 5.0 \\
\hline 21 & $\mathrm{~F}$ & 430 & Died & - & - & - & - \\
\hline \multicolumn{2}{|c|}{ Average } & 385 & & 39 & 22 & 61 & 6.1 \\
\hline
\end{tabular}

$\mathbf{M}=$ Male

$\mathrm{F}=$ Female

Annales de Parasitologie humaine et comparée (Paris), t. 49, $\mathrm{n}^{\circ} 2$ 
Table III. - Recovery of Trichostrongylus axei from guinea pigs infected with 4000 larvae.

\begin{tabular}{|c|c|c|c|c|c|c|c|}
\hline \multirow{2}{*}{$\begin{array}{c}\text { Guineapig } \\
\text { No. }\end{array}$} & \multirow{2}{*}{ Sex } & \multirow{2}{*}{$\begin{array}{l}\text { Weight } \\
\text { (gm) }\end{array}$} & \multirow{2}{*}{$\begin{array}{c}\text { Days } \\
\text { form } \\
\text { infection } \\
\text { to } \\
\text { autopsy }\end{array}$} & \multicolumn{3}{|c|}{ Worms recovered } & \multirow{2}{*}{$\begin{array}{c}\text { Percent } \\
\text { of larvae } \\
\text { adminis- } \\
\text { tered }\end{array}$} \\
\hline & & & & Stomach & $\begin{array}{c}\text { Small } \\
\text { intestine }\end{array}$ & Total & \\
\hline 22 & $\mathbf{F}$ & 360 & 7 & 405 & 0 & 405 & 10.1 \\
\hline 23 & $\mathrm{~F}$ & 640 & 7 & 307 & 13 & 320 & 8.0 \\
\hline 24 & $\mathrm{~F}$ & 385 & 7 & 115 & 15 & 130 & 3.3 \\
\hline 25 & M & 375 & 7 & 450 & 125 & 575 & 14.4 \\
\hline 26 & M & 475 & 7 & 535 & 125 & 660 & 16.5 \\
\hline 27 & M & 370 & Died & - & - & - & - \\
\hline 28 & M & 280 & Died & - & - & - & - \\
\hline \multicolumn{2}{|c|}{ Average } & 412 & & 362 & 56 & 418 & 10.5 \\
\hline 29 & M & 515 & 14 & 500 & 0 & 500 & 12.5 \\
\hline 30 & $\mathbf{M}$ & 550 & Died & - & - & - & - \\
\hline 31 & $\mathbf{M}$ & 410 & 14 & 315 & 112 & 427 & 10.7 \\
\hline 32 & $\mathbf{F}$ & 385 & 14 & 138 & 22 & 160 & 4.0 \\
\hline 33 & $\mathrm{~F}$ & 330 & 14 & 125 & 10 & 135 & 3.4 \\
\hline 34 & F & 320 & 14 & 0 & 0 & 0 & 0.0 \\
\hline 35 & $\mathrm{~F}$ & 240 & Died & - & - & - & - \\
\hline \multicolumn{2}{|c|}{ Average } & 393 & & 216 & 29 & 245 & 6.1 \\
\hline 36 & $\mathbf{F}$ & 360 & 28 & 130 & 150 & 280 & 7.0 \\
\hline 37 & $F$ & 190 & 28 & 435 & 120 & 555 & 14.0 \\
\hline 38 & M & 380 & 28 & 0 & 0 & 0 & 0.0 \\
\hline 39 & M & 610 & 28 & 15 & 5 & 20 & 0.5 \\
\hline 40 & $\mathbf{M}$ & 395 & 28 & 105 & 15 & 120 & 3.0 \\
\hline 41 & M & 340 & 28 & 285 & 65 & 350 & 9.0 \\
\hline 42 & $\mathrm{~F}$ & 315 & Died & - & - & - & - \\
\hline \multicolumn{2}{|c|}{ Average } & 367 & & 162 & 59 & 221 & 5.0 \\
\hline
\end{tabular}

$\mathbf{M}=$ Male

$\mathrm{F}=$ Female

There were great variations in the number of worms recovered from individuals of the same group as well as between the groups. However in general the number of worms increased with the dose of the larvae, but the percentage of worms established decreased with increase in the larval dose. For example, the percentage establishment in the 3 groups of animals autopsied on 28 days after infection was $6.1,5$ and 4.2 for the larval doses of $1,000,4,000$ and 8,000 respectively. Majority 
Table IV. - Recovery of Trichostrongylus axei from guinea pigs infected with 8000 larvae.

\begin{tabular}{|c|c|c|c|c|c|c|c|}
\hline \multirow{2}{*}{$\begin{array}{c}\text { Guineapig } \\
\text { No. }\end{array}$} & \multirow{2}{*}{ Sex } & \multirow{2}{*}{$\begin{array}{c}\text { Weight } \\
(\mathrm{gm})\end{array}$} & \multirow{2}{*}{$\begin{array}{l}\text { Days } \\
\text { from } \\
\text { infection } \\
\text { to } \\
\text { autopsy }\end{array}$} & \multicolumn{3}{|c|}{ Worms recovered } & \multirow{2}{*}{$\begin{array}{c}\text { Percent } \\
\text { of larvae } \\
\text { adminis- } \\
\text { tered }\end{array}$} \\
\hline & & & & Stomach & $\begin{array}{c}\text { Small } \\
\text { intestine }\end{array}$ & Total & \\
\hline 43 & M & 430 & 7 & 240 & 80 & 320 & 4.0 \\
\hline 44 & M & 330 & 7 & 1050 & 15 & 1065 & 13.3 \\
\hline 45 & M & 395 & 7 & 0 & 0 & 0 & 0.0 \\
\hline 46 & $\mathrm{~F}$ & 295 & 7 & 515 & 125 & 640 & 8.0 \\
\hline 47 & $\mathrm{~F}$ & 350 & 7 & 135 & 9 & 144 & 1.8 \\
\hline 48 & $\mathrm{~F}$ & 260 & Died & - & - & - & - \\
\hline 49 & $\mathrm{~F}$ & 280 & 7 & 235 & 120 & 355 & 4.4 \\
\hline \multicolumn{2}{|c|}{ Average } & 334 & & 363 & 58 & 421 & 5.3 \\
\hline 50 & M & 270 & 14 & 115 & 25 & 140 & 1.8 \\
\hline 51 & M & 450 & 14 & 218 & 17 & 235 & 2.9 \\
\hline 52 & M & 500 & 14 & 910 & 15 & 925 & 11.6 \\
\hline 53 & $\mathrm{~F}$ & 280 & 14 & 0 & 0 & 0 & 0.0 \\
\hline 54 & $\mathrm{~F}$ & 255 & 14 & 136 & 234 & 370 & 4.6 \\
\hline 55 & $\mathrm{~F}$ & 525 & 14 & 495 & 65 & 560 & 7.0 \\
\hline 56 & $\mathrm{~F}$ & 230 & 14 & 317 & 23 & 340 & 4.3 \\
\hline \multicolumn{2}{|c|}{ Average } & 359 & & 313 & 54 & 367 & 4.6 \\
\hline 57 & $\mathrm{~F}$ & 235 & 28 & 105 & 15 & 120 & 1.5 \\
\hline 58 & $\mathrm{~F}$ & 190 & 28 & 145 & 25 & 170 & 2.1 \\
\hline 59 & M & 620 & 28 & 240 & 45 & 285 & 3.6 \\
\hline 60 & M & 555 & 28 & 617 & 103 & 720 & 9.0 \\
\hline 61 & M & 430 & 28 & 39 & 29 & 68 & 0.9 \\
\hline 62 & $\mathrm{~F}$ & 290 & Died & - & - & - & - \\
\hline 63 & M & 370 & Died & - & - & - & - \\
\hline \multicolumn{2}{|c|}{ Average } & 384 & & 289 & 43 & 332 & 4.2 \\
\hline
\end{tabular}

$\mathrm{M}=$ Male

$\mathrm{F}=$ Female

of the worms were found in the stomach in all the groups. A comparison of the number of worms recovered on different days after infection indicates that as the period of infection advanced, the worm recoveries decreased. It seems that with advance in the period of infection some worms were thrown off. No difference was observed in the susceptibility of male and female guineapigs. There were deaths in all the groups of animals, but these were due to causes other than parasitic. 
The mean body weight changes of different groups of guineapigs are shown in fig. 2. The control group had gained $64 \mathrm{gm}$. of weight at the end of 4 weeks whereas those dosed with 1,000 and 4,000 larvae had gained only 7.5 and $27 \mathrm{gm}$. respectively. The animals dosed with 8,000 larvae lost $62 \mathrm{gm}$. of weight during the same period. There were no differences in the body weight changes between the male and female guineapigs. The statistical analysis of variance in the body weight between the different doses was highly significant $(\mathrm{F}=5.25, \mathrm{P}<1 \%)$. The

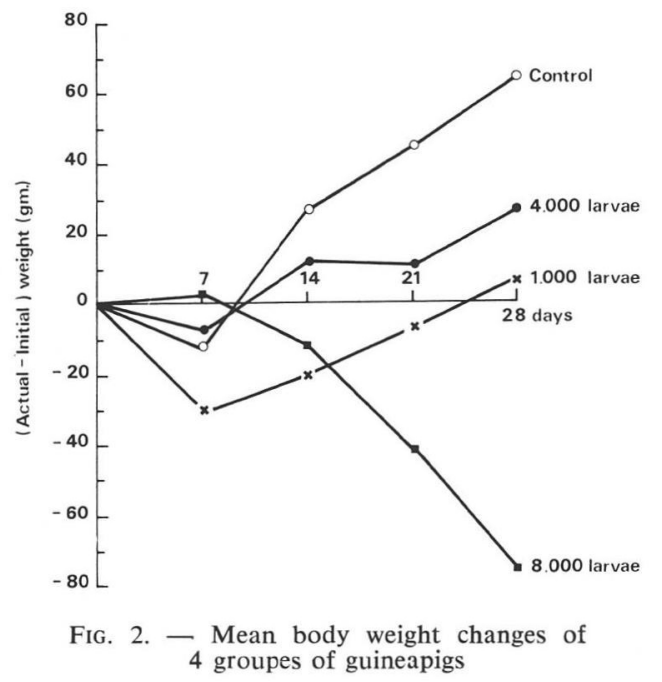

comparison of the averages of different lots by 'Duncan Multiple Range Test' revealed a significant difference in the weight gain (-62 gm.) of 8,000 larval dose group on one side and the other larval doses on the other side.

The worms recovered on 7 th and 14th days after infection were all immature while those recovered on 28th day were mature. The size of the worms from these experimental hosts were comparitively smaller than those from natural hosts of $T$. axei. The worms from guineapigs were significantly smaller than those from rabbits.

\section{Discussion}

Several studies with $T$. axei have shown that there is an inverse relationship between the larval dose and the number of worms recovered (Doran, 1955 ; Kates and Turner, 1960 ; Ross et al., 1968). Leland et al. (1959) observed great variations in worm establishment ( 6 to $59 \%$ ) of this parasite after its passage in various hosts. 
In experimental infections in small laboratory animals the recorded worm recoveries are : 6 to $31 \%$ (Leland and Drudge, 1957), 13.2 to $26.5 \%$ (Sinha, 1967), 1 to $54 \%$ (Ross, 1970) from rabbits ; average $10.5 \%$ from African multimammate mouse, Rattus natalensis, (Leland, 1968); average 46.3\% (Leland, 1963) and $19.4 \%$ (Kates and Thompson, 1968) from Mongolian gerbils and $0 \%$ from white rats (Kates and Thompson, 1968). The worm recoveries in present experiments from rabbits $(15.8$ to $30 \%)$ were in the same range as reported by other workers. The establishment of worms in guineapigs (0 to $15 \%$ ) was much lower than those in rabbits, gerbils and Rattus natalensis. Moreover the individual variations in guineapigs were more marked than in other experimental hosts.

In rabbits, worm recoveries on 7 th, 14 th and 28 th days after infection were identical whereas in guineapigs there were apparent differences in worm recoveries of 28 days and 7 and 14 days after infection. It seems that in guineapigs the worms are thrown off in later period of infection which may be similar to the self cure phenomenon reported for T. retortaeformis in rabbits by Michel (1952) and by several other workers in other parasites.

Dunsmore (1966) working with $T$. retortaeformis and Graphidium stigosum observed that female rabbits carried more worms than the male ones. This he considered to be an effect of sex hormones. Kates and Thompson (1968) found no significant difference by sex in the susceptibility of white rats and Mongolian gerbils to infection with $T$. axei and $T$. colubriformis. Neither in rabbits nor in guineapigs any difference by sex was found in worm recoveries in the present experiments.

The size of $T$. axei from rabbits and guineapigs was smaller than those from natural hosts. This finding is comparable with shorter lengths of worms from other experimental laboratory animals (Leland, 1963, 1968 ; Ross, 1970).

Sturrock (1963) observed that the body weight change is a good measure of parasitic infection in guineapigs with $T$. colubriformis. In present work the infected rabbits gained relatively less weight than the control ones. The difference in body weight gains in guineapigs infected with 8,000 larvae and other groups was highly significant and it seems that the body weight change in guineapigs may be a good indicator of $T$. axei infections at higher dose levels.

Leland and Drudge (1957) found only few T. axei in intestine of some of his experimental rabbits whereas Sinha (1967) recovered relatively high percentages of them from intestine. Since in our experiments both in rabbits and guineapigs majority of the worms were found in stomach, we assume that the stomach is a preferred site for $T$. axei in these experimental hosts.

The present experiments indicate that rabbit can be used as an experimental animal for $T$. axei for different types of studies : pathological, immunological, anthelmintic testing etc. Russel et al. (1966) suggested the use of Obeliscoides cuniculi infections in rabbits as a model for the study of ruminant trichostrongylidosis. It is possible that $T$. axei infections in rabbits may be used as a model for the study of various host parasite phenomenon. 
Guineapigs do not seem to be a suitable host for T. axei. However they can be employed provided following points are born in mind. Adequate number of animals should be used to allow for variations in the susceptibility of guineapigs. This variation may be minimised if animals of similar age, weight, genetic constitution and similar sex are used.

\section{ACKNOWLEDGEMENT}

Greatful thanks are due to Pr. Dr. J. Mortelmans, Institute of Tropical Medicine, Antwerp for providing the facilities for this work and to Pr. Dr. L. Pouplard, Faculty of Veterinary Medicine, Brussels for the facilities in obtaining the infective materials.

\section{References}

Bull (P. C.), 1953. - Parasites of the wild rabbit, Oryctolagus cuniculus (L) in New Zealand. N.Z.J. Sci. Techn., Section B, 34, 341-372.

Cauthen (G. E.), 1958. - Inefficacy of rabbits for testing anthelmintics to be used against gastro-intestinal nematodes of ruminants. J. Parasit., 44, 246.

Ciordia (H.), Bizzell (W. F.), Porter (D. A.) and Dixon (C. F.), 1966. - The effect of culture temperature and age on the infectivity of Trichostrongylus axei and T. colubriformis in rabbits and guineapigs. J. Parasit., 52, 866-870.

Doran (D. J.), 1955. - The course of infection and pathogenic effect of Trichostrongylus axei in calves. Amer. J. Vet. Res., 16, 401-409.

Drudge (J. H.), Leland (S. E.), Wyant (Z. N.) and Elam (G. W.), 1955. - Studies on Trichostrongylus axei (Cobbold, 1879). I. Some experimental host relationships. J. Parasit., 41, 505-511.

DUNSMORE (J. D.), 1966. - Influence of host reproduction on numbers of trichostrongylid nematodes in the European rabbit, Oryctolagus cuniculus (L.). J. Parasit., 52, 1129-1133.

Herlich (H.), 1956. - A digestion method for post mortem recovery of nematodes from ruminants. Proc. Helm. Soc. Wash., 23, 101-103.

KATES (K. C.) and Thompson (D. E.), 1968. - Susceptibility of gerbils and young white rats to simultaneous infection with Trichostrongylus axei and Trichostrongylus colubriformis. Proc. Helm. Soc. Wash., 35, 102-106.

- and Turner (J. H.), 1960. - Experimental trichostrongylosis (axei) in lambs, with a discussion of recent research on this disease in ruminants. Amer. J. Vet. Res., 21, 254-261.

Leland (S. E.), 1963. - Studies on Trichostrongylus axei (Cobbold, 1879). VIII. Some quantitative aspects of experimental infection of the Mongolian gerbil (Meriones unguiculatus). J. Parasit., 49, 617-622.

-, 1968. - Experimental infection of the African multimammate mastomys, Rattus (Mastomys) natalensis, with the minute stomach worm Trichostrongylus axei. J. Parasit., 54, 437-440. 
— and Drudge (J. H.), 1957. - Studies on Trichostrongylus axei (Cobbold, 1879). II. Some quantitative aspects of experimental infections in rabbits. J. Parasit., 43, 160-166.

-, --, Wyant (Z. N.), Elam (G. W.) and Hutzler (L. B.), 1959. - Studies on Trichostrongylus axei (Cobbold, 1879). IV. Some aspects of treatment, pathogenicity and quantification in experimental infections of a horse strain in calves. Amer. J. Vet. Res., 20, 787-794.

Michel (J. F.), 1952. - A self cure in infections of Trichostrongylus retortaeformis and its causation. Nature, London, 169, 881.

Rohrbacher (G. H.), 1960. - The effect of green feed and ascorbic acid upon single experimental infections of Trichostrongylus axei (Cobbold, 1879) in the laboratory rabbit. Amer. J. Vet. Res., 21, 138-143.

Ross (J. G.), 1970. - Trichostrongylus axei host-parasite relationship studies. The influence of passage on cross infection. Res. Vet. Sci., 11, 461-464.

—, Purcell (A.), Dow (C.) and Todd (J. R.), 1968. - Experimental infections of calves with Trichostrongylus axei: Observations on lethal infections. Res. Vet. Sci., 9, 314-318.

Russell (S. W.), Baker (N. F.) and Raizes (G. S.), 1966. - Experimental Obeliscoides cuniculi infections in rabbits: comparison with Trichostrongylus and Ostertagia infections in cattle and sheep. Expt. Parasit., 19, 163-173.

SinHA (P. K.), 1967. - Active immunity against Trichostrongylus axei in sheep and rabbits. Amer. J. Vet. Res., 28, 793-808.

StURrock (R.F.), 1963. - Observations on the use of Trichostrongylus colubriformis (Nematoda) infections in guineapigs for laboratory experiments. Parasitology, 53, 189-199. 